\title{
Long-term dietary segregation of common dolphins Delphinus delphis in the Bay of Biscay, determined using cadmium as an ecological tracer
}

\author{
V. Lahaye ${ }^{1, *}$, P. Bustamante ${ }^{1}$, J. Spitz ${ }^{2}$, W. Dabin ${ }^{2}$, K. Das ${ }^{3}$, G. J. Pierce ${ }^{4}$, F. Caurant ${ }^{1}$ \\ ${ }^{1}$ Laboratoire de Biologie et Environnement Marins, FRE 2727 du CNRS, Université de La Rochelle, Avenue Michel Crépeau, \\ 17042 La Rochelle Cedex, France \\ ${ }^{2}$ Centre de Recherche sur les Mammifères Marins, Institut du Littoral et de l'Environnement, Port des Minimes, \\ Avenue du Lazaret, 17000 La Rochelle, France \\ ${ }^{3}$ Forschung- und Technologiezentrum Westküste, Christian-Albrechts-University, Kiel, Werfstrasse 6, \\ 25761 Büsum, Germany \\ ${ }^{4}$ Department of Zoology, School of Biological Sciences, University of Aberdeen, Tillydrone Avenue, Aberdeen ABZ4 2TZ, UK
}

\begin{abstract}
Dietary studies in marine mammals are traditionally performed by stomach contents analyses, which may be insufficient to determine long-term dietary preferences of these upper level predators. Our primary objective was to test the efficiency of trace metal measurements as complementary tools in dietary studies. Variations in cadmium (Cd) exposure through the diet and its effective renal levels in the short-beaked common dolphin Delphinus delphis were investigated to study the long-term feeding ecology of this predator in the neritic and oceanic waters of the Bay of Biscay. Based upon previous stomach contents analyses, the main prey occurring in the diet of common dolphins were analysed for their Cd contents. Results showed that cephalopods, and especially oceanic Cranchids and Histioteuthids, constituted a major source of Cd for common dolphins. Estimated Cd intake would therefore be 12 times higher in oceanic common dolphins $\left(1400 \pm 65 \mathrm{\mu g} \mathrm{d}^{-1}\right)$ compared to neritic ones $\left(120 \pm 30 \mu \mathrm{g} \mathrm{d}^{-1}\right)$. Accumulation of renal $\mathrm{Cd}$ concentrations with age was 5 times higher in by-caught oceanic dolphins than neritic ones $(p<0.0001)$. Within the neritic area, renal Cd accumulation rate was 2 times higher in by-caught individuals compared to stranded ones $(p=0.002)$. Thus, the use of $\mathrm{Cd}$ concentrations in by-caught dolphins proved efficient for assessing the existence of dietary segregation between neritic and oceanic common dolphins from the Bay of Biscay. However, using Cd data to make inferences about the feeding ecology of stranded animals should be considered cautiously.
\end{abstract}

KEY WORDS: Trace elements $\cdot$ Marine mammals $\cdot$ Diet $\cdot$ Cephalopods $\cdot$ Exposure $\cdot$ Northeastern Atlantic

\section{INTRODUCTION}

The short-beaked common dolphin Delphinus delphis is generally considered the most common small cetacean inhabiting the temperate waters of the northeastern Atlantic. Its distribution covers a large area, which extends from about 35 to $60^{\circ} \mathrm{N}$, with most sightings off southwestern England, southern Ireland, Brittany, and in the Bay of Biscay (Forcada et al. 1990,
Evans 1994). No overall population data are available, but the MICA (Mesure de l'Impact des Captures Accessoires, 1993) and SCANS (Small Cetacean Abundance in the North and adjacent Seas, 1994) surveys provided an estimate for the summer period of about 120000 individuals in the Celtic Sea and south west of this area, from 6 to $20^{\circ} \mathrm{W}$ and 43 to $51^{\circ} \mathrm{N}$ (Goujon 1996). The short-beaked common dolphin is a pelagic species that mainly occurs over the continental shelf, 
notably around the 100 to $200 \mathrm{~m}$ depth contour, or over areas with prominent underwater topographic features (Evans 1994). The presence of this species in offshore waters has also been reported in various areas (Evans 1994, Ferrero \& Walker 1995). In the Bay of Biscay, short-beaked common dolphins show a wide distribution since they are observed both over the continental shelf, the shelf-edge and in deep oceanic waters (Forcada et al. 1990). In addition, these authors suggested a bimodality in distribution by depth for the north part of the Bay of Biscay and proposed the occurrence of 2 different common dolphin populations in the northeastern Atlantic, 1 neritic and 1 oceanic.

Although distributions of cetacean species can often be related to physical oceanographic features such as water depth, it is likely that prey abundance and movements are the most important factors in determining the occurrence and feeding activities of cetaceans (Evans 1987). Furthermore, varied diet exhibited by short-beaked common dolphins in different geographic regions (Evans 1987, Young \& Cockcroft 1994) has been taken to imply that they are opportunistic, i.e. that their diet is likely to reflect the fish and cephalopod abundance in the area where they feed. Hence, dietary studies could also be used to monitor the habitat preferences of these long lived upper level predators. Consequently, if the spatial segregation of common dolphins previously proposed by Forcada et al. (1990) exists in the Bay of Biscay, oceanic dolphins may exhibit different diet composition than neritic ones, without even excluding gene flows between groups. Such dietary differences are to be expected since the neritic and oceanic areas constitute 2 different ecosystems.

The present study aimed to compare dietary preferences of common dolphins from oceanic and neritic areas. The oceanic samples originated from fishery bycatch in the deep waters off the Bay of Biscay (summer 1992-1993) while the neritic samples were comprised of by-caught animals from the continental shelf (winter 2004-2005) plus stranded animals from the French Atlantic coast (2001-2003). Some previous stomach content analyses were carried out on the samples collected between 1992 and 1993 and between 2001 and 2003 (Pierce et al. 2004). Results showed that the prey species present in the stomachs of stranded and oceanic common dolphins were characteristic of each habitat. In addition, oceanic common dolphins would consume 10 times more cephalopods than the neritic ones. Although stomach content analyses can provide valuable data about the food consumed, results are likely to reflect the diet only on a short time scale, i.e. a few days. Such a 'snapshot' of the diet can be problematic since these dietary studies relied on stomach contents from stranded and by-caught animals. The diffi- culty of ensuring that samples are representative of the population is all the more important for strandings, which can include a high number of sick animals. Unhealthy animals may have fed on prey or prey sizes that do not represent the diet of the healthy specimens (Pierce \& Boyle 1991). Furthermore, by-catches could be biased towards animals feeding on commercially important fish in areas frequented by fishermen (Santos et al. 2001). Moreover, food preferences evaluated by this method can vary with both season and year (Santos et al. 2004), which can limit valuable long-term insights into dietary preferences. The use of both stranded and by-caught dolphins, combined with the fact that the oceanic sample was collected over a limited period (summer months) compared to the neritic one (all year), means that we cannot be sure that the animals sampled offshore did not move to inshore areas in other seasons. For these reasons, additional analytical techniques were required to provide a longer time-scale view of a cetacean's diet and to identify potential dietary segregation between neritic and oceanic common dolphins.

Analyses of the fatty constituents of blubber and of carbon and nitrogen stable isotopes in tissues have recently received considerable attention since these techniques provide insight into food preferences, and may potentially overcome some of the difficulties that arise using stomach content analyses (e.g. Iverson et al. 1997, Das et al. 2000a, Hooker et al. 2001, Born et al. 2003). However, the integration of these elements generally occurs over some weeks in the case of fatty acids in the blubber (Thiemann et al. 2004) and 1 to 2 mo for stable isotopes in the muscle (Hobson \& Clark 1992a), which is not long enough to assess the existence of a long-term dietary segregation between habitat for these long-lived predators; common dolphins typically reach 20 to $30 \mathrm{yr}$ of age (Ferrero \& Walker 1995). Stable isotope analyses in hard tissues (teeth and bone) can provide information about diet over a much longer time-scale (e.g. Schoeninger \& De Niro 1984, Hobson \& Clark 1992b) but hard tissues from the 'oceanic' sample were not available for isotope analyses.

The present study explores the utility of trace element measurements in soft tissues to provide additional long-term information on diet. Some previous studies have underlined the potential efficiency of trace elements to provide long-term insights into both feeding and habitat preferences of such upper level predators (e.g. Noda et al. 1995, Sanpera et al. 1996, Das et al. 2000a, Kunito et al. 2002, Born et al. 2003). Among trace elements, cadmium $(\mathrm{Cd})$ is ubiquitous in marine ecosystems due to its natural presence in the earth crust and its additional release by anthropogenic activities (mainly through zinc ore and fossil 
combustion) that reach the ocean through river inputs and atmospheric depositions (Nriagu 1996). Reflecting the natural presence of this toxic metal in the marine environment, marine mammals have developed capacities to accumulate high levels of Cd during their life (Aguilar et al. 1999), with the ability to detoxify it through its binding to metallothioneins (see reviews by Das et al. 2000b). Thus, the concentrations of $\mathrm{Cd}$ can be particularly elevated in the kidneys of marine mammals (e.g. Caurant \& Amiard-Triquet 1995), in which the biological half-life of $\mathrm{Cd}$ is more than $10 \mathrm{yr}$ for mammals (Stoeppler 1991). Given that the main pathway of exposure to this metal for marine mammals is diet (Aguilar et al. 1999) and that the major source of $\mathrm{Cd}$ is feeding on cephalopods (Bustamante et al. 1998, 2002a), Cd concentrations in the kidneys of these upper level predators may constitute a signature of the consumption of cephalopods over a long time-scale. Indeed, the use of $\mathrm{Cd}$ as a tracer for diet has already been demonstrated for grey seals from the Faroe Islands (Bustamante et al. 2004). The authors highlighted the fact that Cd levels in seals were not in accordance with the stomach contents analyses (limited to the summer months), emphasising also that the use of stomach contents data alone is not sufficient when considering feeding over a longer time-scale.

The present study employs a relatively new approach to investigate common dolphin feeding preferences by examining both short-term exposure to $\mathrm{Cd}$ through the diet and effective levels in common dolphin tissues. The approach is based on the hypothesis that if common dolphins have a long-term affinity to specific feeding areas, which are characterised by different biotic and/or chemical environments, significant differences in long-term metal signatures might allow us to distinguish common dolphins from each area. Our objectives were: (1) to provide baseline data on levels of Cd concentrations in the prey previously found in stomach contents; (2) to estimate a value for the short-term exposure to $\mathrm{Cd}$ through the diet for each area, based upon the proportion of prey found in stomachs; (3) to compare renal Cd levels in common dolphins from each area. Since common dolphins from neritic and oceanic areas differ in their consumption of cephalopods on a short time-scale, the hypothesis that $\mathrm{Cd}$ concentrations in their kidneys could discriminate dietary preferences over a long time-scale can be tested for these 2 Atlantic marine food webs.

\section{MATERIALS AND METHODS}

Study area. The Bay of Biscay is a sector of the northeastern Atlantic between 1 to $10^{\circ} \mathrm{W}$, and 43 to $48^{\circ} \mathrm{N}$. This area is characterised by a variable distance of the shelf-edge from the coastline (Fig. 1). Continental shelf width varies from 60 to 100 nautical miles (n mile) in the northern part of the bay (up to $45^{\circ} \mathrm{N}$ ) and is reduced to 25 to $30 \mathrm{n}$ mile in the southern part, reaching $3 \mathrm{n}$ mile at the latitude of the Cape Breton trough. In this study, the oceanic and neritic areas have been distinguished as potential habitats for common dolphins for the north part of the Bay of Biscay, i.e. up to $45^{\circ} \mathrm{N}$.

Dolphin sampling. Between 2001 and 2003, 37 stranded common dolphins (17 males and 20 females) were sampled by the Réseau National Echouage (RNE), co-ordinated by the Centre de Recherche sur les Mammifères Marins (CRMM) from La Rochelle (France), along the north French Atlantic coast, i.e. from 45 to $48^{\circ} \mathrm{N}$ (Fig. 1). The state of decomposition was noted as: (1) very fresh, less than $48 \mathrm{~h}$ after death (serum separates from blood cells); (2) fresh (blood cells do not separate serum, cloudy eyes) or (3) slightly decomposed (skin peeling, moderate smell of decomposition). Given that the continental shelf covers a large area at these latitudes and that the sampled animals were relatively fresh, these dolphins were assumed to have been feeding in the neritic area prior to stranding. After the necropsies, all the col-

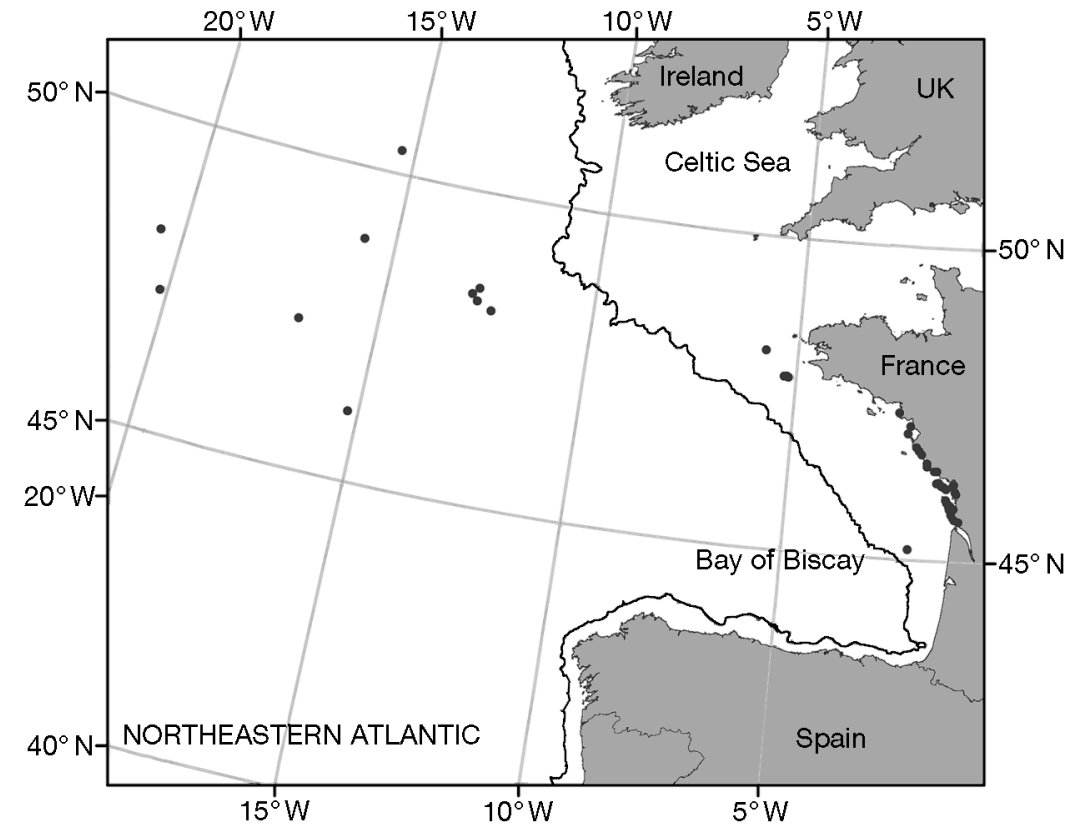

Fig. 1. Delphinus delphis. Locations of sampling of by-caught 'oceanic' ( $\mathrm{n}=10)$, by-caught 'neritic' $(\mathrm{n}=10)$, and stranded $(\mathrm{n}=37)$ dolphins from the Bay of Biscay. The $200 \mathrm{~m}$ isobath is indicated by a black line 
lected tissues (i.e. kidney for $\mathrm{Cd}$ analyses and teeth for age determination) were stored at $-20^{\circ} \mathrm{C}$ until processed in the laboratory. This neritic sample was augmented by 10 by-caught animals ( 2 males and 8 females), which were collected over the continental shelf in the 2004-2005 winter. The oceanic sample was comprised of 10 individuals $(5$ males and 5 females) by-caught during albacore driftnet fishing in oceanic waters from May to September 1993, between 46 and $50^{\circ} \mathrm{N}$, and 9 and $20^{\circ} \mathrm{W}$ (Fig. 1). This collection was conducted by the Institut Français de Recherche pour l'Exploitation de la Mer (IFREMER) from Brest (France) as part of a study on the impact of this fishery on small cetaceans (GERDAU program, see Goujon 1996). Tissue samples were taken at the fishing site and frozen immediately in liquid nitrogen and then kept in a freezer $\left(-20^{\circ} \mathrm{C}\right)$ until metal analyses in the Oceanology Laboratory (Liege, Belgium; Das et al. 2000a).

Other parameters determined during the sampling included total length $(\mathrm{cm})$ and gender. Age was deter- mined at the CRMM of La Rochelle. The procedure consisted of counting Growth Layer Groups (GLGs) from tooth sections, assuming that one GLG equals $1 \mathrm{yr}$ (as described by Perrin \& Myrick 1980).

Prey sampling. Results from previous stomach content analyses allowed the collection of the main prey of common dolphins, aiming to cover the range of sizes found in stomach contents. This prey sampling included 7 species of cephalopod and 11 species of fish (see Table 1). These prey were collected during IFREMER groundfish surveys in the Bay of Biscay, from the continental shelf to the shelf-edge in autumn from 2001 to 2003 (EVHOE cruises survey). During these campaigns, oceanic species were also collected by pelagic trawling over the shelf-edge in the late evening. Prey samples were immediately frozen at $-20^{\circ} \mathrm{C}$ on board and then stored at the laboratory until use. After species determination, each individual was weighed and measured, and due to relatively small sample sizes for several species, individual prey of similar size from the same trawl haul were pooled.

Table 1. Characteristics and Cd levels (means $\pm \mathrm{SD}, \mu \mathrm{g} \mathrm{g}{ }^{-1}$ wet wt) of prey occurring in the diet of common dolphins from the Bay of Biscay. Length: standard length for fish and to mantle length for cephalopods; $\mathrm{n}$ : number of samples analysed; $\mathrm{n}^{*}$ : pooled samples; EV: energetic value

\begin{tabular}{|c|c|c|c|c|c|c|c|c|}
\hline \multirow{3}{*}{ Taxon } & \multicolumn{3}{|c|}{$\longrightarrow$ Prey in diet -} & \multirow{3}{*}{$\begin{array}{l}\text { Length }(\mathrm{cm}) \\
\text { Mean } \pm \mathrm{SD}\end{array}$} & \multirow{2}{*}{\multicolumn{2}{|c|}{$\begin{array}{l}\text { Prey analyzed for } \mathrm{Cd} \\
\quad \mathrm{Cd} \text { levels ( } \mu \mathrm{g} \mathrm{g}^{-1} \text { wet wt) }\end{array}$}} & \multirow{3}{*}{$\mathrm{n}$} & \multirow{3}{*}{$\begin{array}{c}\mathrm{EV} \\
\left(\mathrm{kJ} \mathrm{g}^{-1}\right)\end{array}$} \\
\hline & \multicolumn{2}{|c|}{ Mass frequency } & \multirow{2}{*}{$\begin{array}{l}\text { Length }(\mathrm{cm}) \\
\text { Mean } \pm \mathrm{SD}\end{array}$} & & & & & \\
\hline & Inshore & Offshore & & & Mean \pm SD & Range & & \\
\hline \multicolumn{9}{|l|}{ Fish } \\
\hline \multicolumn{9}{|l|}{ Carangidae } \\
\hline Trachurus trachurus & 18.3 & & $11.7 \pm 3.5$ & $14.1 \pm 0.03$ & $0.039 \pm 0.007$ & $0.034-0.046$ & $3^{*}$ & 5.8 \\
\hline \multicolumn{9}{|l|}{ Clupeidae } \\
\hline Sardina pilchardius & 35.6 & & $19.2 \pm 3.2$ & $19.8 \pm 0.2$ & $0.048 \pm 0.017$ & $0.029-0.060$ & 3 & 10.5 \\
\hline Sprattus sprattus & 4.7 & & $11.4 \pm 2.1$ & $7.5 \pm 0.04$ & $0.028 \pm 0.001$ & $0.027-0.029$ & $3^{*}$ & 8.3 \\
\hline \multicolumn{9}{|l|}{ Engraulidae } \\
\hline Engraulis encrasicolus & 11.7 & & $12.1 \pm 2.6$ & $11.7 \pm 0.2$ & $0.019 \pm 0.004$ & $0.015-0.022$ & $3^{*}$ & 6.7 \\
\hline \multicolumn{9}{|l|}{ Gadidae } \\
\hline Merlangius merlangus & 3.1 & & $19.7 \pm 4.1$ & $14.1 \pm 0.3$ & $0.005 \pm 0.000$ & & $3^{*}$ & 4.1 \\
\hline Micromesistius poutassou & 6.9 & & $12.2 \pm 4.2$ & $14.1 \pm 0.2$ & $0.012 \pm 0.003$ & $0.009-0.014$ & $3^{*}$ & 4.5 \\
\hline Trisopterus minutus & 3.7 & & $8.0 \pm 3.6$ & $8.5 \pm 0.1$ & $0.016 \pm 0.003$ & $0.013-0.019$ & $3^{*}$ & 5.7 \\
\hline Gobididae & 1.0 & & & & & & & \\
\hline Pomatochistus minutus & & & $4.5 \pm 0.5$ & $6.4 \pm 0.11$ & $<0.002$ & $<0.002$ & $3^{*}$ & 4.8 \\
\hline \multicolumn{9}{|l|}{ Myctophidae } \\
\hline Notoscopelus kroeyeri & & 29.5 & $4.6 \pm 2.0$ & $7.6 \pm 0.9$ & $0.017 \pm 0.010$ & $0.009-0.028$ & 3 & 6.5 \\
\hline \multicolumn{9}{|l|}{ Paralepididae } \\
\hline Arctozenus risso & & 0.6 & $13.0 \pm 2.7$ & $13.1 \pm 1.8$ & $0.020 \pm 0.008$ & $0.011-0.026$ & 3 & 5 \\
\hline \multicolumn{9}{|l|}{ Scombridae } \\
\hline Scomber scombrus & 6.2 & & $29.0 \pm 7.7$ & $27.5 \pm 1.1$ & $0.041 \pm 0.006$ & $0.034-0.046$ & 3 & 9.2 \\
\hline \multicolumn{9}{|l|}{ Cephalopod } \\
\hline \multicolumn{9}{|l|}{ Cranchiidae } \\
\hline Teuthowenia megalops & & 17.0 & $11.6 \pm 2.7$ & 18.1 & 1.32 & & 1 & 5 \\
\hline \multicolumn{9}{|l|}{ Histioteuthidae } \\
\hline Histioteuthis sp. & & 6.3 & $2.3 \pm 8.0$ & $2.63 \pm 0.55$ & $0.500 \pm 0.146$ & $0.385-0.665$ & 3 & 5 \\
\hline Loliginidae & 2.8 & & $18.5 \pm 11.5$ & & & & & \\
\hline Loligo forbesi & & & & $19.1 \pm 3.2$ & $0.077 \pm 0.015$ & $0.060-0.090$ & 3 & 5 \\
\hline L. vulgaris & & & & $16.8 \pm 6.3$ & $0.113 \pm 0.010$ & $0.102-0.121$ & 3 & 5 \\
\hline Ommastrephidae & & 0.2 & 14.3 & & & & & \\
\hline Illex coindetii & & & & $13.7 \pm 4.8$ & $0.220 \pm 0.026$ & $0.200-0.250$ & 3 & 4.9 \\
\hline Todarodes sagitattus & & & & 13.7 & 0.28 & $0.230-0.320$ & 2 & 5 \\
\hline Todaropsis eblanae & & & & $14.9 \pm 1.3$ & $0.216 \pm 0.147$ & $0.121-0.385$ & 3 & 5.5 \\
\hline
\end{tabular}


Metal analyses were carried out on whole prey in order to reflect the exposure to predators.

Heavy metal analyses. All equipment used in sample processing was cleaned, and subsequently decontaminated for $24 \mathrm{~h}$ in a solution comprised of $35 \mathrm{ml} \mathrm{HNO}_{3}$ (65\%) and $50 \mathrm{ml} \mathrm{HCl} \mathrm{(36 \% )} \mathrm{in} 1 \mathrm{l}$ of Milli-Ro quality water. Fresh samples were freeze-dried and ground to powder. Each sample was then treated in duplicate.

Prior to $\mathrm{Cd}$ analyses, 2 aliquots (approximately $200 \mathrm{mg}$ ) of each homogenised dry sample were digested with $3.5 \mathrm{ml}$ of $65 \% \mathrm{HNO}_{3}$ at $60^{\circ} \mathrm{C}$ for $3 \mathrm{~d}$. The digested contents were then diluted to $10 \mathrm{ml}$ in Milli-Q quality water. $\mathrm{Cd}$ content was then assayed using a flame (Varian 250 Plus) with deuterium background correction, and graphite furnace (Hitachi Z-5000) atomic-absorption spectrophotometer with Zeeman background correction. Metal concentrations in tissues are reported in $\mu \mathrm{g} \mathrm{g}^{-1}$ wet weight (wet wt).

Quality control was assessed using dogfish liver DOLT-2 and DOLT-3 (NRCC). These standards were treated and analysed under the same conditions as the samples. Our results were in agreement with the certified values (respectively, $20.6 \pm 0.4$ vs. $20.8 \pm 0.5$ for DOLT-2 and $19.2 \pm 0.4$ vs. $19.4 \pm 0.6 \mu \mathrm{g} \mathrm{g}^{-1}$ dry wt for DOLT-3). Detection limits were 0.002 and $0.4 \mathrm{\mu g} \mathrm{g}^{-1}$ dry wt, for furnace and flame AAS, respectively.

Data treatment. Statistical analyses were performed using XL-STAT. All the concentrations which were below the detection limit were replaced with 'dummy values' that were half of the detection limit (Gibbons \& Coleman 2001).

Calculation of exposure to metal through the diet: Cd levels in whole prey were used to calculate the exposure to this metal through the diet using:

$$
\begin{gathered}
\mathrm{BMR}=70 \cdot \mathrm{M}^{0.75} \\
\mathrm{FMR}=\mathrm{BMR} \cdot \mathrm{AE} \cdot \mathrm{AM} \\
\mathrm{DCR}_{\mathrm{i}}=\left(\mathrm{FMR} \cdot \mathrm{F}_{\mathrm{i}}\right) / \mathrm{EV}_{\mathrm{i}}
\end{gathered}
$$

Exposure $\mathrm{i}$ to $\mathrm{n}=\Sigma_{\mathrm{i} \text { to } \mathrm{n}} \mathrm{DCR}_{\mathrm{i}} \cdot[\mathrm{Cd}]_{\mathrm{i}}$

where BMR $\left(\mathrm{kJ} \mathrm{d}^{-1}\right)$ is the basal metabolic rate of common dolphins, FMR $\left(\mathrm{kJ} \mathrm{d}^{-1}\right)$ is the field metabolic rate; DCR $\left(\mathrm{g} \mathrm{d}^{-1}\right)$ is the daily consumption rate of prey, and $i$ is a prey species reported in the diet. The BMR was estimated according to the standard mammalian metabolic model of Kleiber (1975), reinvestigated for marine mammals by Hunter et al. (2000). An average body mass ( $\mathrm{M}$, in $\mathrm{kg}$ ) of $90 \mathrm{~kg}$ was used for common dolphins (Collet 1981). BMR was converted to FMR by multiplying BMR by factors accounting for assimilation efficiency (AE) and active metabolism (AM). Assimilation efficiency was assumed to be $80 \%$ following Hinga (1979), resulting in a multiplication factor of 1.25 .
Active metabolism in cetaceans has been established at approximately 2 to 5 times BMR (Hinga 1979). A value of 2.5 times BMR was chosen at near the bottom of that range (Kenney et al. 1997). The DCR was obtained by multiplying the reconstituted biomass of each prey $\left(\mathrm{F}_{\mathrm{i} i}\right.$ see Pierce et al. 2004) in the diet by the FMR, divided by the energetic value of each prey $\left(\mathrm{EV}_{\mathrm{i}}\right.$, in $\mathrm{kJ} \mathrm{g}^{-1}$; see Table 1) according to the values of Evans (1987) and Desmercières (unpubl. data, see Table 1). Finally the exposure to Cd (Eq. 4, $\mathrm{g} \mathrm{d}^{-1}$ ) through the diet was obtained by multiplying the DCR by the level of Cd in whole prey ([Cd], $\mathrm{Mg} \mathrm{g}^{-1}$ wet wt) for all prey occurring in the diet of common dolphins. Estimates of uncertainty are based upon the standard deviation of $\mathrm{Cd}$ concentrations for each prey.

Variations of metal concentrations in common dolphins: Variation in Cd concentrations in dolphins was investigated using analysis of covariance (ANCOVA). As age is an important factor influencing the accumulation of metals (Aguilar et al. 1999), this parameter was used as the co-variate in the ANCOVA. The factors tested were state of decomposition, gender, and origin of samples and their first-order interaction with age, depending on the suitability of each sample set. When significant, the ANCOVA was followed by Fisher multi-comparison tests.

\section{RESULTS}

\section{Exposure to Cd through the diet}

Cd levels of the prey species examined in this study are given in Table 1, along with the mean length of the individuals sampled, their energetic value, and their proportion and size in the diet of common dolphins from neritic and oceanic areas.

Cephalopods exhibited much higher levels of $\mathrm{Cd}$ than fishes, with respective mean concentrations of $0.291 \pm$ 0.302 and $0.022 \pm 0.016 \mu \mathrm{g} \mathrm{g}^{-1}$ wet wt. The high variability exhibited among cephalopods (104\%) is partly due to Teuthowenia megalops, which exhibited the highest concentration of $1.32 \mu \mathrm{g} \mathrm{g}^{-1}$ wet wt (Table 1). Moreover, a comparison between cephalopod families revealed decreasing levels of Cd with Cranchids > Histioteuthids > Ommastrephids > Loliginids (Fig. 2). In the case of fish, the maximal levels were obtained in Clupeids, Scombrids and Carangids, in which concentrations were at least twice those of the other fishes (Table 1).

Taking into account the contribution by weight of each prey to the diet, a 12 times more elevated exposure to Cd was obtained for oceanic common dolphins compared to neritic ones (Fig. 3). This particularly elevated estimation for offshore dolphins $\left(1400 \pm 65 \mu \mathrm{g} \mathrm{d}^{-1}\right)$ is linked to the important contribution of cephalopods 


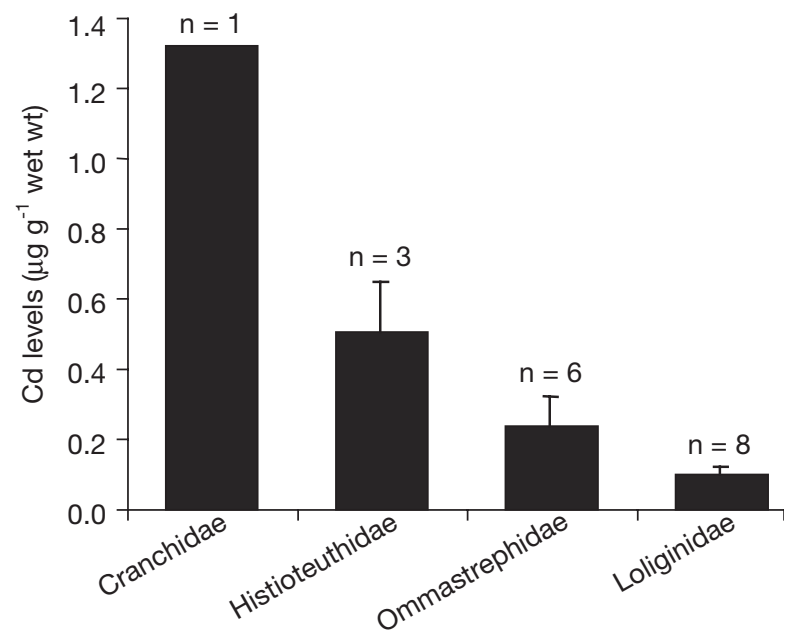

Fig. 2. Mean $(+\mathrm{SD})$ whole body Cd concentrations $\left(\mu \mathrm{g} \mathrm{g}^{-1}\right.$ wet wt) of 4 cephalopod families from the Bay of Biscay

in the calculation (98\%, see Fig. 3), and especially that of Teuthowenia megalops ( $86 \%$ ). On the contrary, the relative contribution of fish in the calculation for inshore dolphins reached $88 \%$ (Fig. 3), which accounts for the low exposure obtained. Furthermore, it should be underlined that the calculation of exposure through the prey analysed is representative of the diet for neritic dolphins but the exposure may be underestimated for oceanic dolphins since the species analysed for $\mathrm{Cd}$ comprised $94 \%$ by mass of the diet for inshore dolphins but only $54 \%$ by mass of the diet for offshore dolphins (Table 1). The lower percentage of the prey analysed for the oceanic area is linked to the difficulty of collecting all the oceanic species for which both occurrence and diel vertical migration pattern are poorly known.

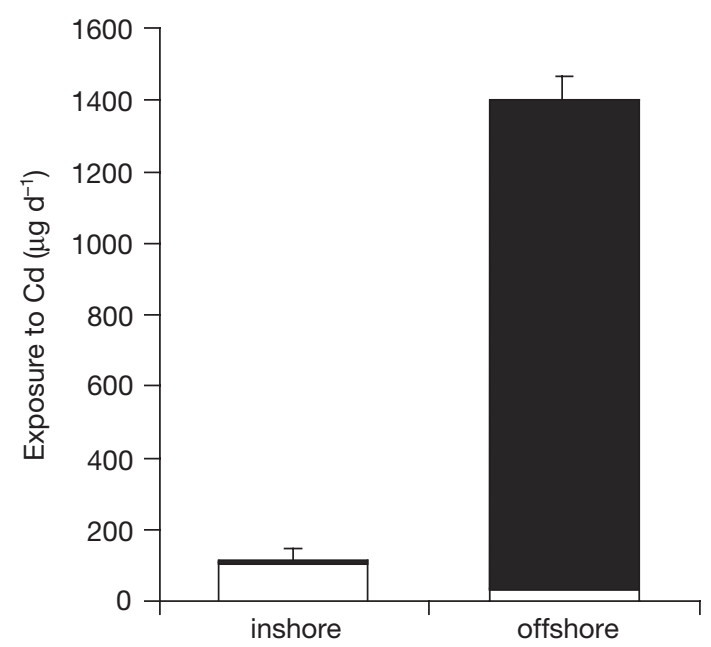

Fig. 3. Delphinus delphis. Contribution of fish (in white) and cephalopods (all families, in black) in the Cd exposure $\left(\mu \mathrm{g} \mathrm{d}^{-1}\right)$ of neritic and oceanic dolphins: calculations were made with 94 and $54 \%$ of the prey reported in the diet, respectively

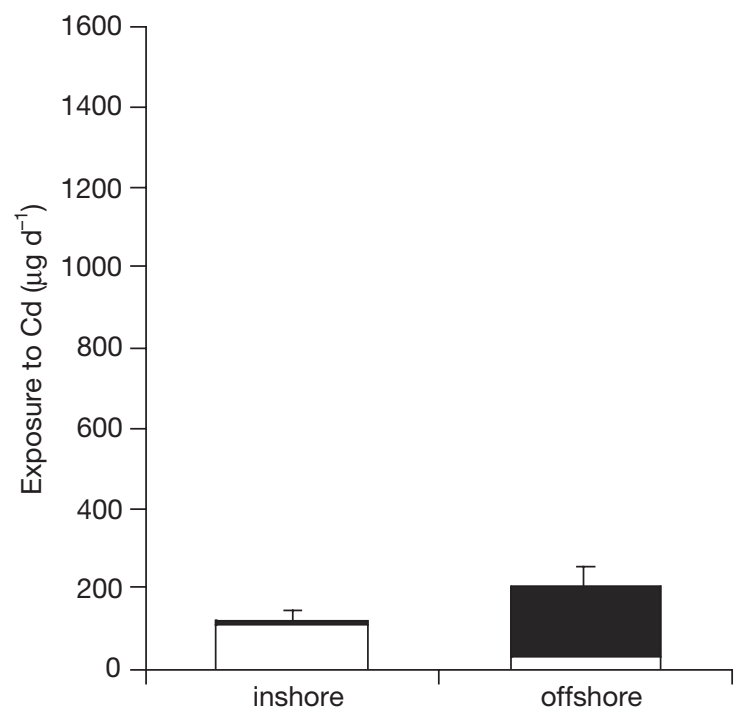

Fig. 4. Delphinus delphis. Contribution of fish (in white) and cephalopods (without Teuthowenia megalops, in black) in the $\mathrm{Cd}$ exposure $\left(\mu \mathrm{g} \mathrm{d}^{-1}\right)$ of oceanic and neritic dolphins: calculations were made with 94 and $37 \%$ of the prey reported in the diet, respectively

Given that Teuthowenia megalops was the prey that showed the highest contribution in the calculation for oceanic dolphins, the same approach was conducted without using data for this species. The probable underestimation of the resultant exposure was also emphasised since a further $17 \%$ of prey (the contribution by mass of T. megalops) were thus not used in calculations (Table 1). However, this second calculation indicated a $\mathrm{Cd}$ exposure 2 times higher for oceanic dolphins compared to neritic ones (Fig. 4).

\section{Renal Cd levels in predators}

The ANCOVA confirmed the significant influence of age on Cd concentrations $(p<0.0001$; Table 2$)$. The state of decomposition of stranded dolphins did not significantly influence $\mathrm{Cd}$ concentrations $(\mathrm{p}=0.938)$. In addition, there were no significant differences in Cd bioaccumulation between male and female for by-caught oceanic dolphins and stranded animals ( $p>0.05)$, which enabled us to pool genders from each area for further comparisons. Thus, the origin of samples and the age were the most important factors explaining renal $\mathrm{Cd}$ variability in dolphins $(\mathrm{p}<0.0001)$ with $52.5 \%$ of the observed variation being explained by age and $43.2 \%$ by the interaction of this factor and the origin of sample. Indeed, Cd concentrations in oceanic by-caught dolphins were about 4 times higher than neritic ones $(\mathrm{p}<0.0001)$, with respective mean levels of $16.3 \pm 14.0$ and $4.35 \pm$ $2.89 \mathrm{\mu g} \mathrm{g}^{-1}$ wet wt. The high standard deviations are the 
Table 2. Delphinus delphis. Significance of the factors influencing Cd concentrations in the kidneys of neritic and oceanic dolphins (analyses by ANCOVA). ANCOVA results give the $F$-value, the percent of variation explained by the modeling in parentheses and the associated probability (p). Results of Fisher multi-comparison test are presented in pairs, with D, the reduced difference and $p$, the associated probability. Significant values are in bold. nd: values not determined as this sample was not suitable for testing the influence of this factor (i.e. 2 males and 8 females)

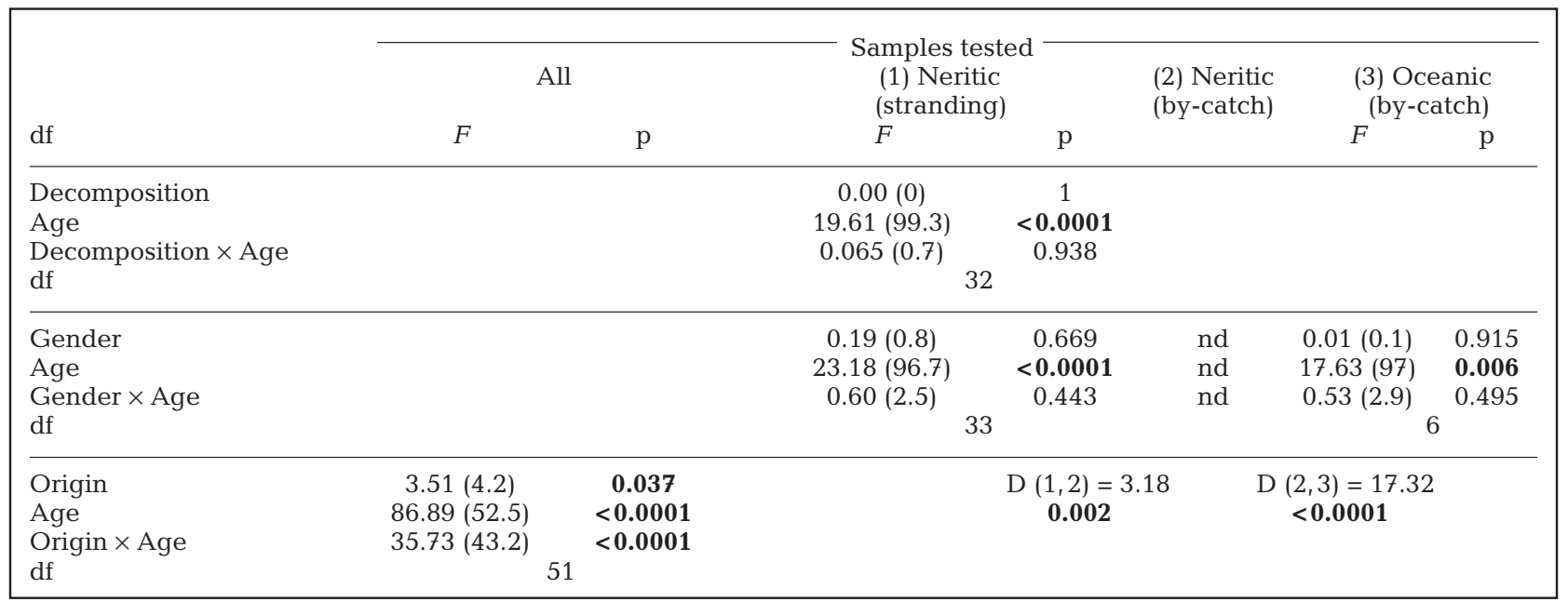

consequence of the increase in concentration with age, with a rate of $\mathrm{Cd}$ bioaccumulation 5 times higher in oceanic by-caught dolphins than in neritic ones (Fig. 5). Moreover, among neritic samples, stranded animals displayed 2 times lower Cd levels $\left(1.66 \pm 1.64 \mu \mathrm{g} \mathrm{g}^{-1}\right.$ wet wt) than by-caught ones ( $p=0.002$; Table 2 ) although the range of concentrations was similar for the 2 samples (i.e. 0.15 to 9.34 and 0.34 to $9.08 \mu \mathrm{g} \mathrm{g}^{-1}$ wet wt, respectively for stranding and by-catch).

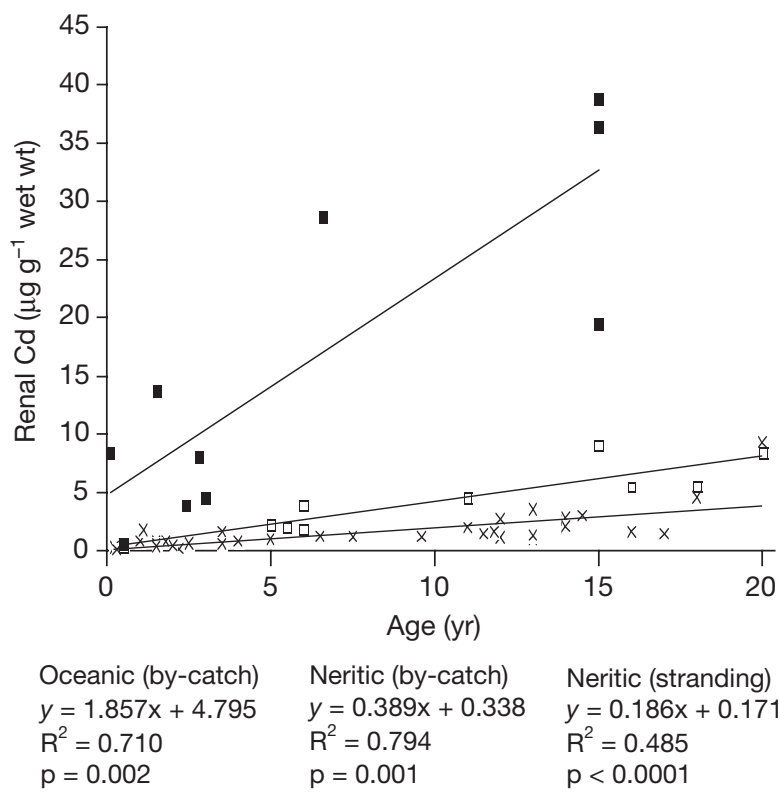

Fig. 5. Delphinus delphis. Renal Cd ( $\mathrm{g} \mathrm{g} \mathrm{g}^{-1}$ wet wt) as a function of age in by-caught oceanic ( $\square$ ) and neritic ( $\square$ ) dolphins, plus stranded individuals $(\times)$ from the Bay of Biscay

\section{DISCUSSION}

Elevated concentrations of $\mathrm{Cd}$ in marine mammals are usually ascribed to a diet in which cephalopods and/or crustaceans predominate (Hanamaka et al. 1982, Honda \& Tatsukawa 1983, Noda et al. 1995, Sanpera et al. 1996, Das et al. 2000a, Kunito et al. 2002, Bustamante et al. 2004). Yet, attempts to compare the intake through the diet with effective levels in predators remain scarce (Caurant \& Amiard-Triquet 1995, Bustamante et al. 1998). Hence, this study aimed to calculate a global $\mathrm{Cd}$ exposure for common dolphins from the Bay of Biscay by examining a combination of prey species which occur in a high mass proportion in the diet. Although the selection of these prey species was based upon stomach analyses from stranded and bycaught individuals, the reliability of the prey chosen as representative of the short-term diet can be supported by the relatively high number of stomach contents analysed ( $\mathrm{r}>60$ for each area), which may avoid the influence of intra-individual variation linked to the use of stranded and by-caught dolphins. Note that the common dolphins analysed for metals constituted a subsample of the set used for stomach content analyses.

\section{Dietary sources of Cd for common dolphins in the Bay of Biscay}

As expected, cephalopods exhibited far higher $\mathrm{Cd}$ levels than fish (i.e. 13 times; Table 1), which concurs with previous studies (Hanamaka et al. 1982, Bustamante et al. 1998). Cd is mainly bioaccumulated in the 
digestive gland of cephalopods, which contain up to $98 \%$ of the total body Cd in some species (e.g. Miramand \& Bentley 1992, Bustamante et al. 2002b), and exhibit very slow Cd turn-over (viz. higher than the cephalopod life; Bustamante et al. 2002b). The high bioavailability of $\mathrm{Cd}$ in the digestive gland indicates a high potential for the trophic transfer of this metal to upper level predators such as marine mammals (Bustamante et al. 2002a). Thus, given that crustaceans represented less than $1 \%$ of stomach contents mass (Pierce et al. 2004), cephalopods may constitute a major source of Cd for common dolphins in the Bay of Biscay.

Among cephalopods, the highest Cd level was found for a single specimen of the Cranchid squid, Teuthowenia megalops, with a concentration of $1.32 \mu^{g^{-1}} \mathrm{~g}^{-1}$ wet wt. Even if the number of the prey analysed was low and did not allow robust statistical comparison, Cd levels in squids would be different between families with a decrease of $\mathrm{Cd}$ concentration in the following pattern: Cranchids $>$ Histioteuthids $>$ Ommastrephids $>$ Loliginids (Fig. 2). Minimal data exist for Cranchids and Histioteuthids, but the Ommastrephids also have higher burdens of $\mathrm{Cd}$ than the Loliginids for the Bay of Biscay, the Celtic Sea and around the Faroe Islands (Bustamante et al. 1998). Loliginids are considered as a neritic family while Histioteuthids and Cranchids are found in the oceanic area (Nesis 1987). Given that Ommastrephids occur in both inshore and offshore waters, with migrations over long distances between feeding and breeding grounds during their life cycle (Nesis 1987), they are likely to integrate the exposure to $\mathrm{Cd}$ from both areas and to also exhibit an intermediate burden compared to the strictly oceanic and neritic cephalopods.

Both Teuthowenia megalops and Histioteuthis sp. are found mostly in the productive waters of the northern temperate Atlantic Ocean (Voss 1985, Voss et al. 1998). Likewise, it is now well established that the geographical distribution of $\mathrm{Cd}$ in offshore waters is similar to that of the labile micronutrient phosphorus (Boyle et al. 1976). Like phosphate, Cd is enriched in the surface waters of upwelling regions relative to areas of lower productivity and is depleted in the surface ocean relative to the deeper waters because of its uptake by organisms at the surface and regeneration from sinking biological debris deeper in the water column (Boyle et al. 1976). As the main Cd source for cephalopods is dietary (Koyama et al. 2000, Bustamante et al. 2002b), and the oceanic squids of this study were collected over the shelf-edge, the elevated concentrations of $\mathrm{Cd}$ in Histioteuthids and Cranchids may be due to the consumption of prey highly contaminated with $\mathrm{Cd}$ in the productive waters of the shelfedge. However, the validity of using prey caught over the shelf-edge is questionable since dolphins were sampled over deeper waters. As the vertical water col- umn distribution of Cd over the shelf-edge did not differ to that from the open ocean (Cotté-Krief et al. 2002), cephalopods from the oceanic part of the Bay of Biscay may also feed in $\mathrm{Cd}$ enriched waters which may expose them to high levels of $\mathrm{Cd}$. This hypothesis is supported by other studies on oceanic cephalopods which also reported very high $\mathrm{Cd}$ concentrations in their tissues (e.g. Martin \& Flegal 1975).

\section{Dietary segregation between oceanic and neritic common dolphins}

The exposure estimated for common dolphins in the oceanic area reached $1400 \pm 65 \mu \mathrm{g} \mathrm{d}^{-1}$ with $98 \%$ of this intake owing to the consumption of cephalopods (Fig. 3), and especially Teuthowenia megalops (compare Figs. 3 \& 4). This estimation of exposure to $\mathrm{Cd}$ in the oceanic area may be biased since only 1 specimen of T. megalops could be collected. However, the estimations carried out with and without this species (Figs. 3 \& 4) could be expected to remain under estimated since only $53.4 \%$ of the prey occurring in the diet of oceanic dolphins were analysed (Table 1). Furthermore, the prey for which no $\mathrm{Cd}$ data were available comprised an important proportion of cephalopods (Gonatidae and Onychoteuthidae, i.e. $22 \%$ of the overall diet). In contrast to the oceanic dolphins, the exposure estimated for neritic dolphins took into account a larger proportion of their diet, with $94 \%$ (by mass) of the prey present in stomachs being analysed for Cd (Table 1). Although the contribution of fish in the diet of neritic dolphins was elevated (88\%), Cd levels were nevertheless increased (Fig. 4) by the important consumption of the fatty fishes Sardina pilchardius (35.6\%), Trachurus trachurus (18.3\%) and Engraulis encrasicolus (11.7\%), which exhibited the highest levels of $\mathrm{Cd}$ among fishes (Table 1). Despite uncertainties in the estimation, the exposure to $\mathrm{Cd}$ calculated for the oceanic area would be much higher than the one obtained for the neritic area (Fig. 3).

Such an elevated global exposure for offshore dolphins compared to inshore ones is the consequence of the much greater importance of cephalopods in the diet of dolphins from the oceanic area compared to the neritic one, i.e. 45.7 versus $4.8 \%$ (Pierce et al. 2004). The difference in $\mathrm{Cd}$ exposure through the consumption of cephalopods is emphasised by the higher Cd levels found in Cranchids, Histioteuthids and Ommastrephids, which would be preferentially consumed by oceanic dolphins compared with that of Loliginids, which may be the main source of cephalopods for neritic dolphins (Table 1). Although we detected no consistent differences between $\mathrm{Cd}$ levels in male and female dolphins (Table 2), further 
consideration of variation in exposure between genders, age classes and/or seasons is necessary to better understand the transfer of $\mathrm{Cd}$ through diet.

When looking at effective renal Cd concentrations in common dolphins, age and origin of samples were the 2 factors explaining the $\mathrm{Cd}$ variations in dolphins ( $\mathrm{p}<$ 0.0001; Table 2). In the neritic area, stranded animals displayed 2 times lower $\mathrm{Cd}$ levels than by-caught ones $(\mathrm{p}=0.002)$. The $\mathrm{Cd}$ levels found in the kidneys of the stranded common dolphins collected between 2001 and 2003 were similar to those previously obtained by Holsbeek et al. (1998) for common dolphins stranded between 1977 and 1990 in the same area (Fig. 6). Therefore, the observed differences of renal Cd levels between stranded and by-caught 'neritic' animals may probably also be the result of the sample source than inter-annual variations (2001-2003 vs. 2004-2005). Indeed, stranded animals may not really be representative of a healthy population, which is likely to affect metal concentrations for this biological material. Differences in metal levels between by-catch and stranding have been reported for mercury (Strand et al. 2005), but, to the best of our knowledge, not for $\mathrm{Cd}$.

The Cd levels in by-caught common dolphins, however, displayed a similar trend to that obtained by the calculation of the exposure; the mean Cd levels being 4 times higher in oceanic dolphins than in neritic ones. Such differences in Cd levels between areas could be attributed to temporal variations of $\mathrm{Cd}$ in the environment since oceanic dolphins were collected in 1992-1993, whereas neritic ones were sampled in 2004-2005. The combination of our data with those of Holsbeek et al. (1998) suggests that Cd levels in the kidneys of common dolphins from the Bay of Biscay

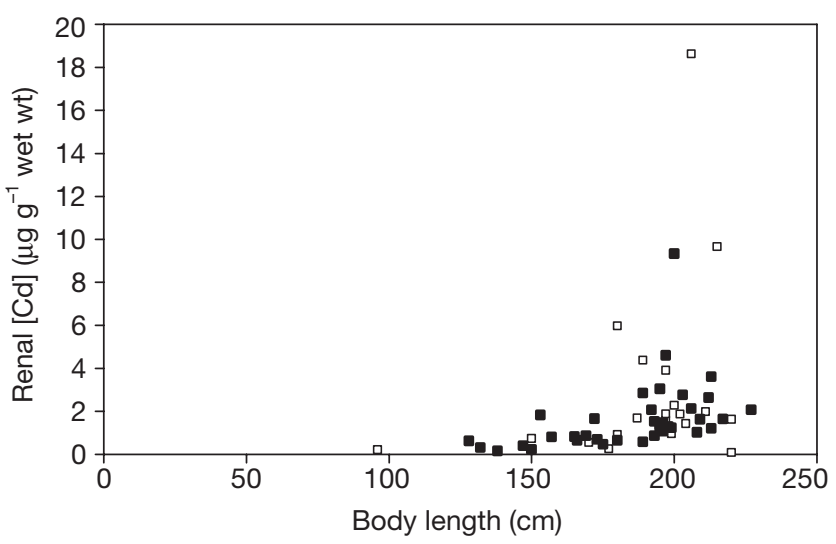

Fig. 6. Delphinus delphis. Renal $\mathrm{Cd}\left(\mu \mathrm{g} \mathrm{g}^{-1}\right.$ wet wt) as a function of body length $(\mathrm{cm})$ in common dolphins stranded along the French Atlantic coast between 2001 and 2003 (this study; - and between 1977 and 1990 (Holsbeek et al. 1998; ㅁ). Data from Holsbeek et al. (1998) are converted in wet wt on the basis of the dry wt:wet wt ratio obtained in this study (i.e. 0.23) have not changed substantially during these last $20 \mathrm{yr}$ (Fig. 6). Furthermore, Cd levels in the neritic prey from the present study are similar to those previously reported (e.g. Amiard-Triquet et al. 1983, Bustamante et al. 1998). Thus, the observed difference of renal $\mathrm{Cd}$ levels between neritic and oceanic common dolphins may also be the consequence of a long-term integration of $\mathrm{Cd}$ in 2 distinct food webs.

Differences in Cd levels between different areas have already been reported in several species and were attributed to variations in feeding behaviour among areas (Hanamaka et al. 1982, Born et al. 2003), chemical water properties (Noda et al. 1995), or metabolism (Sanpera et al. 1996). With common dolphins from the Bay of Biscay, the variations of renal Cd observed may indeed be the consequence of different dietary preferences between areas, but the high concentrations exhibited by oceanic dolphins may also reflect a signature of the particular geochemical conditions that would occur offshore. As well, the low carbon isotopic ratio, reported for muscle of oceanic common dolphins were consistent with an oceanic feeding behaviour on a mid-time-scale (i.e. some months; Das et al. 2000a). Therefore, we can assess the existence of a long-term dietary segregation between common dolphins from inshore and offshore waters of the Bay of Biscay. The higher rate of Cd bioaccumulation in the kidneys of oceanic dolphins compared to neritic ones ( $p<0.0001$; Fig. 5$)$ could be linked to the clear difference in bioavailability of $\mathrm{Cd}$ in the prey (Bustamante et al. 2002a) and to their different feeding behaviour. However, a difference in metabolism of dolphins between areas could also be possible. In this context, the analysis of both morphometric data and growth curves will enable the investigation of biological characteristics for these groups of dolphins. The combination of dietary studies, biological characteristics and genetics will allow us to determine the degree of differences between these 2 groups of common dolphins and to assess the existence of 2 populations in the Bay of Biscay, as previously suggested by Forcada et al. (1990). The identification of common dolphin stocks in the northeastern Atlantic would also be relevant in terms of conservation and management of these populations.

\section{CONCLUSIONS}

Our investigation showed that the consumption of cephalopods was a major Cd exposure route to common dolphins, providing insights into the feeding behaviour of both prey and predators. At the prey scale, the elevated levels of $\mathrm{Cd}$ obtained in oceanic cephalopods would appear to be the consequence of their feeding behaviour and the chemical particularity of the area where they feed. The collection of more oceanic squid samples 
is, however, needed to confirm the different burdens seen in coastal and oceanic cephalopods, and to determine the $\mathrm{Cd}$ bioavaibility in oceanic cephalopods in order to evaluate its potential for the transfer to top predators.

The concordance of the estimation of the Cd exposure through the diet and effective Cd levels in predators constitutes a preliminary stage for the modelling of the bioaccumulation of this metal in marine mammals. In future, the estimation of $\mathrm{Cd}$ intake through diet should take into account the variability of each parameter involved in the calculation of the FMR, as well as variations linked to age classes and gender.

In addition, this approach appeared to be an efficient tool for increasing ecological knowledge of common dolphins in the Bay of Biscay, since the use of $\mathrm{Cd}$ as a metallic tracer confirmed the existence of a dietary segregation between oceanic and neritic dolphins on a long-term scale. Genetic techniques will have to be used to improve knowledge of the state of the 2 identified groups in common dolphins in the Bay of Biscay. Finally, the differences in Cd levels between stranded and by-caught animals would have to be confirmed by a larger sampling, but the results obtained here suggest that metal levels in stranded animals should be considered cautiously when inferring feeding preferences.

Acknowledgements. This work was supported by the European program BIOCET (EC: EVK3-CT-2000-00027) and by a research grant from the Conseil Régional de Poitou-Charentes of V.L. We are very grateful to all the participants of the French national stranding network (RNE) and fishermen for the collection of dolphin samples and to IFREMER for facilitating the prey sampling. We thank A. Guerra and A. González of the Instituto de Investigaciones Marinas for the species determination of oceanic squids.

\section{LITERATURE CITED}

Aguilar A, Borrel A, Pastor T (1999) Biological factors affecting variability of persistent pollutant levels in cetaceans. Cetacean Res Manag Spec Iss 1:83-116

Amiard-Triquet C, Amiard JC, Robert JM, Metayer C, Marchand J, Martin JL (1983) Etude comparative de l'accumulation biologique de quelques oligo-éléments métalliques dans l'estuaire interne de la Loire et les zones néritiques voisines (Baie de Bourgneuf). Cah Biol Mar 24:105-118

Born EW, Outridge P, Riget FF, Hobson KA, Dietz R, Øien N, Haug T (2003) Population substructure of North Atlantic minke whales (Balaenoptera acutorostrata) inferred from regional variation of element and stable isotopic signatures in tissues. J Mar Syst 43:1-17

Boyle EA, Sclater F, Edmond JM (1976) On the marine geochemistry of cadmium. Nature 263:42-44

Bustamante P, Caurant F, Fowler SW, Miramand P (1998) Cephalopods as a vector for the transfer of cadmium to top marine predators in the north-east Atlantic Ocean. Sci Total Environ 220:71-80
Bustamante P, Cosson RP, Gallien I, Caurant F, Miramand P (2002a) Cadmium detoxification processes in the digestive gland of cephalopods in relation to accumulated cadmium concentrations. Mar Environ Res 53:227-241

Bustamante P, Teyssié JL, Fowler SW, Cotret O, Danis B, Miramand P, Warnau M (2002b) Biokinetics of zinc and cadmium accumulation and depuration at different stages in the life cycle of the cuttlefish Sepia officinalis. Mar Ecol Prog Ser 231:167-177

Bustamante P, Morales CF, Mikkelsen B, Dam M, Caurant F (2004) Trace element bioaccumulation in grey seals Halichoerus grypus from the Faroe Islands. Mar Ecol Prog Ser 267:291-301

Caurant F, Amiard-Triquet C (1995) Cadmium contamination in pilot whales Globicephala melas: source and potential hazard to the species. Mar Pollut Bull 30(3):207-210

Collet A (1981) Biologie du dauphin commun Delphinus delphis L. en Atlantique Nord-Est. PhD thesis, University of Poitiers

Cotté-Krief MH, Thomas AJ, Martin JM (2002) Trace metal $(\mathrm{Cd}, \mathrm{Cu}, \mathrm{Ni}$ and $\mathrm{Pb})$ cycling in the upper water column near the shelf edge of the European continental margin (Celtic Sea). Mar Chem 79:1-26

Das K, Lepoint G, Loizeau V, Debacker V, Dauby P, Bouquegneau JM (2000a) Tuna and dolphin associations in the North-East Atlantic: evidence of different ecological niches from stable isotope and heavy metal measurements. Mar Pollut Bull 40(2):102-109

Das K, Debacker V, Bouquegneau JM (2000b) Metallothioneins in marine mammals. Cell Mol Biol 46(2):283-294

Evans PGH (1987) The natural history of whales and dolphins, 1st edn. Christopher Helm, London

Evans WE (1994) Common dolphin, white-bellied porpoiseDelphinus delphis Linnaeus, 1758. In: Ridgway SH, Harrison R (eds) Handbook of marine mammals, Vol 5. Academic Press, London, p 191-225

Ferrero RC, Walker WA (1995) Growth and reproduction of the common dolphin, Delphinus delphis Linnaeus, in the offshore waters of the Pacific Ocean. Fish Bull 93:483-494

Forcada J, Aguilar A, Evans PGH, Perrin W (1990) Distribution of common and striped dolphins in the temperate waters of the Eastern North Atlantic. Eur Res Cet 4:64-65

Gibbons RD, Coleman DE (2001) Statistical methods for detection and quantification of environmental contamination. John Wiley \& Sons, New York

Goujon M (1996) Captures accidentelles du filet maillant dérivant et dynamique des populations de dauphins au large du Golfe de Gascogne. PhD thesis, ENSAR Rennes

Hanamaka T, Itoo T, Mishima S (1982) Age-related change and distribution of cadmium and zinc concentrations in the steller sea lion (Eumetopias jubata) from the coast of Hokkaido, Japan. Mar Pollut Bull 13(2):57-61

Hinga KR (1979) The requirements of whales in the southern hemisphere. Deep-Sea Res 26:569-577

Hobson KA, Clark RG (1992a) Assessing avian diets using stable isotopes: I. Turnover of carbon-13. Condor 94: 181-188

Hobson KA, Clark RG (1992b) Assessing avian diets using stable isotopes: II. Factors influencing diet-tissue fractionation. Condor 94:189-197

Holsbeek L, Siebert U, Joiris CR (1998) Heavy metals in dolphins stranded on the French Atlantic coast. Sci Total Environ 217:241-249

Honda K, Tatsukawa R (1983) Distribution of cadmium and zinc in tissues and organs, and their age-related changes in striped dolphins, Stenella coeruleoalba. Arch Environ Contam Toxicol 12:543-550 
Hooker SK, Iverson SJ, Ostrom P, Smith SC (2001) Diet of northern bottlenose whales inferred from fatty-acid and stable isotope analyses of biopsy samples. Can J Zool 79: 1442-1454

Hunter AMJ, Trites AW, Pauly D (2000) Estimates of basal metabolic and feeding rates for marine mammals from measurements of maximum body length. P Comp Nutr Soc 2000:103-106

Iverson SJ, Frost KJ, Lowry LF (1997) Fatty acid signatures reveal fine scale structure of foraging distribution of harbour seals and their prey in Prince William Sound, Alaska. Mar Ecol Prog Ser 151:255-271

Kenney RD, Scott GP, Thompson TJ, Winn HE (1997) Estimates of prey consumption and trophic impacts of cetaceans in the USA northeast continental shelf ecosystem. J Northw Atl Fish Sci 22:155-171

Kleiber M (1975) The fire of life, an introduction to animal energetic, 2nd edn. RE Kreiger, New York

Koyama J, Nanamori N, Segawa S (2000) Bioaccumulation of waterborne and dietary cadmium by oval squid, Sepioteuthis lessoniana, and its distribution among organs. Mar Pollut Bull 40(11):961-967

Kunito T, Watanabe I, Yasunaga G, Fujise Y, Tanabe S (2002) Using trace elements in skin to discriminate the populations of minke whales in southern hemisphere. Mar Environ Res 53:175-197

Martin JH, Flegal AR (1975) High copper concentrations in squid livers in association with elevated levels of silver, cadmium and zinc. Mar Biol 30:51-55

Miramand P, Bentley D (1992) Concentration and distribution of heavy metals in tissues of two cephalopods, Eledone cirrhosa and Sepia officinalis, from the French coast of the English Channel. Mar Biol 114:407-414

Nesis KN (1987) Cephalopods of the world: squid, cuttlefishes, octopuses, and allies. TFH Publications, Neptune City, NJ

Noda K, Ichihashi H, Loughlin TR, Baba N, Kiyota M, Tatsukawa R (1995) Distribution of heavy metals in muscle, liver and kidney of northern fur seal (Callorhinus ursinus) caught off Sanriku, Japan and from the Pribilof islands, Alaska. Environ Pollut 90(1):51-59

Nriagu JO (1996) A history of global metal pollution. Science 272:223-224

Perrin WF, Myrick Jr AC (1980) Age determination of toothed

Editorial responsibility: Otto Kinne (Editor-in-Chief), Oldendorf/Luhe, Germany whales and sirenians. Rep Int Whal Comm, Spec Issue 3 Pierce GJ, Boyle PR (1991) A review of methods for diet analysis in piscivorous marine mammals. Oceanogr Mar Biol 29: 409-486

Pierce GJ, Santos MB, Learmonth JA, Smeenk C and 20 others (2004) Bioaccumulation of persistent organic pollutants in small cetaceans in European waters: transport pathways and impact on reproduction. Final Report to the European Commission's Directorate General for Research on Project EVK3-2000-00027

Sanpera C, Gonzales M, Jover L (1996) Heavy metals in two populations of North Atlantic fin whales (Balaenoptera physalus). Environ Pollut 91(3):299-307

Santos MB, Clarke MR, Pierce GJ (2001) Assessing the importance of cephalopods in the diets of marine mammals and other top predators: problems and solutions. Fish Res 52: 121-139

Santos MB, Pierce GJ, Learmonth JA, Reid RJ, Ross HM, Patterson IAP, Reid DG, Beare D (2004) Variability in the diet of harbour porpoises (Phocoena phocoena) in Scottish waters 1992-2003. Mar Mamm Sci 20(1):1-27

Schoeninger MJ, De Niro MJ (1984) Nitrogen and carbon isotopic composition of bone collagen from marine and terrestrial animals. Geochim Cosmochim Acta 48:625-639

Stoeppler M (1991) Cadmium. In: Merian E, Clarson TW (eds) Metal and their compounds in the environment. $\mathrm{VCH}_{\text {, }}$ New York, p 803-851

Strand J, Larsen MM, Lockyer C (2005) Accumulation of organic compounds and mercury in harbour porpoises (Phocoena phocoena) from the Danish waters and West Greenland. Sci Total Environ 350:59-71

Thiemann GW, Budge SM, Iverson SJ (2004) Determining blubber fatty acid composition: a comparison of in situ direct and traditional methods. Mar Mamm Sci 20: 284-295

Voss NA (1985) Systematics, biology and biogeography of the cranchiid cephalopod genus Teuthowenia (Oegopsida). Bull Mar Sci 36:1-85

Voss NA, Nesis KN, Rodhouse PG (1998) The cephalopod family Histioteuthidae (Oegopsida): Systematics, biology, and biogeography. Smithson Contr Zool 586(2):293-372

Young DD, Cockcroft VG (1994) Diet of common dolphins (Delphinus delphis) off the south-east coast of southern Africa: opportunism or specialization? J Zool 234:41-53

Submitted: August 12, 2004; Accepted: July 10, 2005 Proofs received from author(s): November 14, 2005 